\title{
Investigation of Upper Extremity Functionality in Adolescent Patients with Idiopathic Scoliosis Undergoing Scoliosis Surgery
}

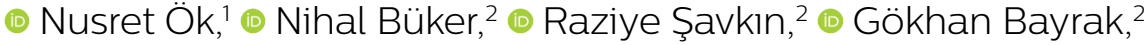

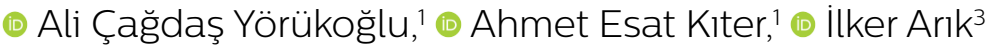

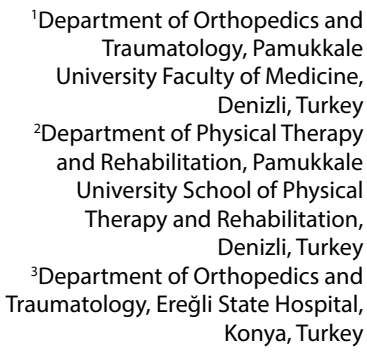

Submitted: 05.12.2018 Accepted: 11.03.2019

Correspondence: Nihal Büker Pamukkale Üniversitesi Fizik Tedavi ve Rehabilitasyon Yüksekokulu 20200 Denizli, Turkey

E-mail: nasuk@pau.edu.tr

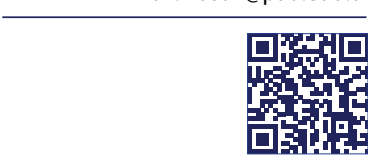

Keywords: Adolescent idiopathic scoliosis; DASH-T; SRS-22.

This work is licensed under a Creative Commons Attribution-NonCommercial 4.0 International License.

\begin{abstract}
Objective: The effect of adolescent idiopathic scoliosis (AIS) on shoulder dysfunction and upper limb functionality is still not poorly understood. In this study, we aimed to investigate the effects of AIS on upper extremity functionality and quality of life.
\end{abstract}

Methods: Thirty-seven patients who had undergone surgery for adolescent idiopathic scoliosis participated in this study. Upper extremity functionality was evaluated using Turkish version of the Disabilities of the Arm, Shoulder and Hand (DASH-T) questionnaire, handgrip strength Jamar hand dynamometer, and health-related quality of life was assessed using SF-36, and Scoliosis Research Society-22r Health-Related Quality of Life questionnaire (SRS22).

Results: The mean age of the patients was $17.08 \pm 2.96$ years and the mean follow-up period was $34.44 \pm 25.37$ months. The average DASH-T score was found 14.79 \pm 17.35 . Patients quality of life scores was good level. The average right hand grip strength was $19.84 \pm 8.89$ $\mathrm{kg}$ while left hand grip strength was $18.97 \pm 8.0 \mathrm{l} \mathrm{kg}$. There was no statistically significant difference between right and left hand grip strength $(p=0.67)$. There was a moderate negative correlation with DASH-T and SRS-22 pain $(r=-0.46, p=0.0 I)$ and SF-36 pain $(r=0.54, p=0.0 I)$, and a weak positive correlation with SF-36 social function $(r=-0.38, p=0.03)$. There was no statistically significant relationship between Cobb angle $(\Delta)$ and SRS-22, SF-36, DASH-T and hand grip strength.

Conclusion: Further studies may examine the effects of surgery on upper extremity functionality, hand-grip strength, and quality of life in patients with AIS using both objective and patient-reported assessment tools.

\section{INTRODUCTION}

Adolescent idiopathic scoliosis (AIS) is a three-dimensional spinal deformity that affects $5.2 \%$ of the children aged between I I-18 years without identifiable etiology ${ }^{[1,2]}$ AIS is more common in girls than boys and affects $1-4 \%$ of the adolescents in early adolescence..$^{[3]}$

Structural changes in AIS may affect the functionality and quality of life. Even in individuals with a low degree of curvature, it may be difficult to perform daily living activities. ${ }^{[4]}$ Changes in body posture and scapula mechanics may cause pain and asymmetry in the scapular region. ${ }^{[5]}$

Scapula plays an important role in supporting shoulder function. Considering the anatomical relationship between the scapula and thoracic cage, differences in muscle length on the concave and convex sides in postural problems, such as AIS cause scapular disposition and orientation changes during resting. ${ }^{[6,7]}$ Therefore, scoliotic curvature may affect the scapulothoracic function and abnormal scapular movement may cause glenohumeral dysfunction. [8,9] In particular, deficits in the posterior tilt and upward rotation of the scapula may increase the risk of subacromial impingement syndrome and subsequent rotator cuff pathology. ${ }^{[10]}$

In studies performed, the relationship between scapular kinematics and shoulder complex has generally been examined from a biomechanical perspective. ${ }^{[6,10,1]]}$ However, there are very few studies on the effects of abnormal scapular movement patterns due to changing scapulothoracic kinematics on patient's daily living activities. ${ }^{[12]}$ 
The mobility and stability performance of the upper extremity in daily living activities requires normal functionality of the shoulder complex, and the correct contribution of the scapulathoracic joint is important for this function. Studies have examined the relationship between body posture/shape, abnormal scapula kinematics and shoulder dysfunction, ${ }^{[4,6,10,11,13]}$ but the extent of shoulder dysfunction in AIS and its effects on the functioning of the upper extremity are not yet well understood. Therefore, in this study, we aimed to investigate the effects of AIS on upper extremity functionality and health-related quality of life.

\section{MATERIALS AND METHODS}

All patients who had undergone surgery for AIS between 2008 and 2015 in the Department of Orthopedics and Traumatology were included in this study. Participation in this study was on a voluntary basis, and each patient included in this study was provided detailed information about this study and written informed consent of the patients and/or their families was obtained. The study was approved by Pamukkale University Non-invasive Clinical Research Ethics Committee (27.1 I.2018/22).

\section{Descriptive data}

Descriptive data of the patients were recorded.

Scoliosis-related quality of life questionnaire: Scoliosis Research Society-22r Health-Related Quality of Life questionnaire (SRS-22) was used to evaluate the quality of life associated with scoliosis. This questionnaire is a simple and practical quality of life questionnaire which was created specifically for individuals with scoliosis. Turkish validity and reliability study were performed by Alanay et al. ${ }^{[14]}$ (2005). The SRS-22 questionnaire consists of five subgroups as pain, self-image/appearance, degree of function/activity, mental health and treatment satisfaction. The total score ranges from I to 5 points, and the higher score indicates a better patient quality of life.

Overall quality of life questionnaire: Short-form 36 (SF-36) was used to evaluate the overall quality of life of the patients. ${ }^{[15]}$ The validity and the reliability of the SF-36 into Turkish were performed by Kocyigit et al. ${ }^{[16]}$

The questionnaire consists of 36 items that measure the eight dimensions of physical function, social function, role limitations due to physical problems, role limitations due to emotional problems, mental health, energy/vitality, the general perception of pain and health. The subscales evaluate health between $0-100$ points and 0 indicates poor health status and 100 indicates good health status.

\section{Assessment of the functional status of the upper extremity}

The Turkish version of the disabilities of the arm, shoulder and hand (DASH-T) questionnaire was used to evaluate the functionality of upper extremity. ${ }^{[1]]}$ The Turkish validity and reliability study of the questionnaire was performed by Düger et al. ${ }^{[18]}$ (2006).

The questionnaire consists of 30 questions and evaluates the functional status of the upper extremity subjectively according to the 5-point Likert-type scale. The sum of the scores obtained is converted into a total score ranging from 0 to 100 points, and the high score indicates poor functional status.

Hand-grip strenght: Hand-grip strength of the patients was measured with Jamar hand-held dynamometer in accordance with the standards recommended by the American Association of Hand Therapists. Measurements were performed with the patient sitting with his/her elbow at $90^{\circ}$ flexion, forearm in a neutral position and radial side up, using resistance at 2 . level $(3.75 \mathrm{~cm})$. Patients were asked to squeeze the dynamometer with maximum force. Measurements were performed bilaterally three times and the average result was recorded in kilograms $(\mathrm{kg}){ }^{\left[{ }^{[9]}\right.}$

Measurement of the degree of the curvature: Cobb method, which is accepted as the standard measurement method, was used to determine the degree of curvature.

\section{Statistical analysis}

The data was analyzed using SPSS 24.0 (IBM Corp. Released 2016. IBM SPSS Statistics for Windows, Version 24.0. Armonk, NY: IBM Corp.) package program. Continuous variables were given as mean \pm standard deviation and categorical variables as numbers and percentages. Pearson Correlation Coefficient was used to determine the relationships between the variables.

\section{RESULTS}

A total of 37 patients ( 31 female and 6 male) participated in this study. The mean age of the patients was $17.08 \pm 2.96$ years, and the mean follow-up period was $34.44 \pm 25.37$ months. In addition, $8.1 \%$ of the patients perform exercise regularly descriptive data of the patients are given in Table I.

The mean value of the major curvature was $49.00 \pm 9.78^{\circ}$ preoperatively and $14.74 \pm 6.47^{\circ}$ postoperatively according to Cobb angle measurement $(p=0.00)$.

SRS-22 questionnaire subscale (pain $X=4.07 \pm 0.48$, selfimage $X=3.93 \pm 0.65$, function $X=4.19 \pm 0.59$, mental health $X=3.62 \pm 0.63$ and satisfaction $(X=4.19 \pm 0.87)$ and total score $(X=3.99 \pm 0.37)$ were a good level. SF-36 subscale scores (physical functioning $X=79.57 \pm 18.04$, physical role limitation $X=72.50 \pm 34.54$, emotional role limitation $X=72.38 \pm 33.80$, energy $X=67.90 \pm 18.35$, mental health $X=71.08 \pm 20.74$, social functioning $X=74.28 \pm 22.01$, pain $X=69.70 \pm 18.18$ and general health $X=69.45 \pm 14.63$ ) was good level (Table 2).

The average DASH-T score was found $14.79 \pm 17.35$. The average right hand grip strength was $19.84 \pm 8.89 \mathrm{~kg}$ while 
Table I. Descriptive data of the patients

\begin{tabular}{lcc}
\hline Variables & \multicolumn{2}{c}{ Patients $(\mathbf{n}=37)$} \\
\cline { 2 - 3 } & Min-Max & Mean \pm SD \\
\hline Age (year) & $11-25$ & $17.08 \pm 2.96$ \\
Height $(\mathrm{cm})$ & $127-184$ & $161.89 \pm 0.12$ \\
Weight $(\mathrm{kg})$ & $25-74$ & $52.54 \pm 8.67$ \\
Body mass index $\left(\mathrm{kg} / \mathrm{m}^{2}\right)$ & $13.92-27.34$ & $20.05 \pm 2.88$ \\
Education (years) & $5-14$ & $10.27 \pm 2.19$ \\
Follow-up period (months) & $10.97-80.50$ & $34.44 \pm 25.37$ \\
\hline & $\mathbf{n}$ & $\%$ \\
\hline Gender & & \\
$\quad$ Female & 31 & 83.8 \\
$\quad$ Male & 6 & 16.2 \\
Dominant upper extremity & & \\
$\quad$ Right & 36 & 97.3 \\
$\quad$ Left & 1 & 2.7 \\
Exercising regularly & & \\
$\quad$ Yes & 3 & 91.9 \\
$\quad$ No & 34 & \\
\hline
\end{tabular}

Min: Minimum; Max: Maximum; SD: Standard deviation.

Table 2. SRS-22, SF-36, DASH-T and hand grip strength scores of the patients

\begin{tabular}{lcc}
\hline Variables & \multicolumn{2}{c}{ Patients (n=37) } \\
\cline { 2 - 3 } & Min-Max & Mean \pm SD \\
\hline SRS-22 & & \\
Pain & $3-5$ & $4.07 \pm 0.48$ \\
Image & $2.60-5$ & $3.93 \pm 0.65$ \\
Function & $3-5$ & $4.19 \pm 0.59$ \\
Mental health & $1.40-4.80$ & $3.62 \pm 0.63$ \\
Treatment satisfaction & $2-5$ & $4.19 \pm 0.87$ \\
Total score & $3.36-4.72$ & $3.99 \pm 0.37$ \\
SF-36 & & \\
Physical functioning & $25-100$ & $79.57 \pm 18.04$ \\
Physical role limitation & $0-100$ & $72.50 \pm 34.54$ \\
Emotional role limitation & $0-100$ & $72.38 \pm 33.80$ \\
Energy & $20-100$ & $67.90 \pm 18.35$ \\
Mental health & $16-100$ & $71.08 \pm 20.74$ \\
Social functioning & $20-100$ & $74.28 \pm 22.01$ \\
Pain & $20-100$ & $69.70 \pm 18.18$ \\
General health perception & $40-95$ & $69.45 \pm 14.63$ \\
DASH-T & $0-100$ & $14.79 \pm 17.35$ \\
Hand grip strength (kg) & & \\
Right & $4-39$ & $19.84 \pm 8.89$ \\
Left & $4-34$ & $18.97 \pm 8.01$ \\
\hline
\end{tabular}

SRS-22: Scoliosis Research Society-22r Health-Related Quality of Life; SF-36: Short-form 36; DASH-T: Disabilities of the arm, shoulder and hand questionnaire; Min: Minimum; Max: Maximum; SD: Standard deviation.
Table 3. The relationship between Cobb angle $(\Delta)$ and SRS-22, SF-36, DASH-T and hand grip strength

\begin{tabular}{lcc}
\hline Variables & \multicolumn{2}{c}{ Cobb angle $(\boldsymbol{\Delta})(\mathbf{n}=\mathbf{3 7})$} \\
\cline { 2 - 3 } & $\mathbf{r}$ & $\mathbf{p}^{*}$ \\
\hline SRS-22 & & \\
Pain & 0.12 & 0.53 \\
Image & 0.01 & 0.94 \\
Function & 0.23 & 0.23 \\
Mental health & -0.18 & 0.34 \\
Treatment satisfaction & 0.03 & 0.87 \\
Total score & 0.07 & 0.69 \\
SF-36 & & \\
Physical functioning & -0.07 & 0.71 \\
Physical role limitation & -0.12 & 0.54 \\
Emotional role limitation & -0.06 & 0.75 \\
Energy & -0.06 & 0.74 \\
Mental health & -0.09 & 0.66 \\
Social functioning & -0.35 & 0.07 \\
Pain & -0.18 & 0.38 \\
General health perception & -0.02 & 0.91 \\
DASH-T & -0.19 & 0.35 \\
Hand grip strength & & \\
Right & -0.12 & 0.57 \\
Left & -0.05 & 0.80 \\
\hline
\end{tabular}

*Pearson Correlation Analysis. SRS-22: Scoliosis Research Society-22r Health-Related Quality of Life; SF-36: Short-form 36; DASH-T: Disabilities of the arm, shoulder and hand questionnaire.

left hand grip strength was $18.97 \pm 8.01 \mathrm{~kg}$ (Table 2). There was no statistically significant difference between right and left hand grip strength $(p=0.67)$.

There was no statistically significant relationship between Cobb angle $(\Delta)$ and SRS-22, SF-36, DASH-T and hand grip strength (Table 3).

There was a moderate negative correlation with DASH-T and SRS-22 pain $(r=-0.46, p=0.01)$ and SF-36 pain $(r=0.54$, $p=0.01$ ), and a weak positive correlation with SF-36 social function $(r=-0.38, p=0.03)$ (Table 4).

\section{DISCUSSION}

The condition of the trunk and shoulder complex and the contribution of the scapulathoracic joint are important to ensure functionality in daily living activities. While there have been many studies on scapular orientation and shoulder levels in AIS, ${ }^{[5,10,11,20]}$ few studies have been conducted to determine the disability, symptoms and function of upper extremity due to scoliosis. ${ }^{[12,21]}$ We aimed to determine the effects of AIS on upper extremity functionality and health-related quality of life. In our study, we observed that upper extremity functionality was not affected because of AIS and there was no difference between right and left extremity grip strengths. There was no relation- 
Table 4. The relationship between DASH-T and SRS-22, SF-36 and hand grip strength

\begin{tabular}{lcc}
\hline Variables & \multicolumn{2}{c}{ DASH-T $(\mathbf{n}=\mathbf{3 7})$} \\
\cline { 2 - 3 } & $\mathbf{r}$ & $\mathbf{p}^{*}$ \\
\hline SRS-22 & & \\
$\quad$ Pain & -0.46 & 0.01 \\
Image & -0.08 & 0.66 \\
Function & -0.17 & 0.32 \\
Mental health & -0.22 & 0.21 \\
Treatment satisfaction & -0.01 & 0.92 \\
Total score & -0.31 & 0.07 \\
SF-36 & & \\
Physical functioning & -0.17 & 0.33 \\
Physical role limitation & -0.08 & 0.66 \\
Emotional role limitation & 0.01 & 0.94 \\
Energy & -0.11 & 0.54 \\
Mental health & -0.14 & 0.46 \\
Social functioning & -0.38 & 0.03 \\
Pain & -0.54 & 0.01 \\
General health perception & -0.11 & 0.55 \\
Hand grip strength & & \\
Right & -0.14 & 0.44 \\
Left & -0.08 & 0.68 \\
\hline
\end{tabular}

"Pearson Correlation Analysis. SRS-22: Scoliosis Research Society-22r Health-Related Quality of Life; SF-36: Short-form 36; DASH-T: Disabilities of the arm, shoulder and hand questionnaire.

ship between changes in the degree of curvature and upper extremity function, hand grip strength and quality of life. We also found that decrease in pain was found to increase upper extremity functionality.

In patients with non-surgical AIS, scapular kinematics in different positions of the upper extremity were compared with healthy subjects. ${ }^{[14,20,22]}$ Upper extremity function was generally evaluated with objective clinical measurements such as range of motion instead of selfreported questionnaires. Turgut et al. ${ }^{[6]}$ (2017) reported that scapular position and orientation changes are observed in both concave and convex sides in patients with AIS and peak humerothoracic elevation in resting position is decreased. Rapp van Roden al. ${ }^{[20]}$ (2018) showed that, patient reported shoulder functional outcomes (DASH-T) were lower in patients with AIS than healthy subjects, but this dysfunction was not associated with scapula kinematics. In addition, the authors reported no relationship between DASH score and degree of curvature. In our study, we used DASH-T and found that upper extremity functionality was good and there was no correlation between the degree of curvature of upper extremity functionality.

Lin et al. ${ }^{[2]}(2010)$ reported that rehabilitation programs should be planned considering the kinematic linkage among the thoracic spine, scapula and arm, and the high LT muscular activity on the convex side in patients with idiopathic scoliosis. Yu et al. ${ }^{[23]}$ (2012) showed that both dominant and nondominant hand grip strength is low in patients with AIS. We found that there was no statistically difference between the hand grip strength of the dominant and nondominant sides, and there was no correlation between the degree of curvature, upper extremity functionality, and grip strength. However, only $8.1 \%$ of the patients exercised regularly. As stated by previous studies, ${ }^{[20-22]}$ we think that rehabilitation and exercise training should be given importance in order to minimize functional disabilities in patients with AIS and that patients should be encouraged to exercise regularly.

Shoulder level, trunk symmetry and cosmetic results were generally evaluated after AIS surgery, ${ }^{[24-26]}$ and to our knowledge, there is only one study evaluating postoperative upper extremity functionality. The authors stated that, with postoperative stretching and strengthening rehabilitation patient would regain full function of the upper extremity in terms of strength, active range of motion, and activities of daily living. ${ }^{[27]}$ In our study, although none of the patients were underwent rehabilitation program, patients upper extremity functions were good after surgery. However, since we do not perform preoperative evaluation, we think that the beneficial or detrimental effects of surgical correction of AIS on upper extremity function should be investigated in further studies.

We found a relationship between upper extremity functionality and quality of life-pain subscale. Even in the third postoperative year, we think that pain affects upper extremity functionality and independence in daily living activities in patients with AIS. Quality of life questionnaires examine the severity of pain, drug use, and limitation of work and daily living activities due to pain. The lack of a specific measurement tool that questions the localization and severity of pain is the limitation of our study, but the pain perceived by the patient may be caused by the back or scapula region. Future studies may investigate the effects of postoperative pain on upper extremity functionality with more specific tools.

Evidence suggests that surgery in AIS may lead to clinically significant improvement in the patient self-image, and there is no evidence for worsening quality of life after surgery. ${ }^{[28]}$ Studies showed that surgical treatment of AIS improved the patient's quality of life at 5-year ${ }^{[29]}$ and 25 year follow-up, ${ }^{[30]}$ although there was no correlation between quality of life and Cobb angle, curve correction, or type of instrumentation. ${ }^{[3]}$ We obtained good quality of life results but no correlation was found between quality of life and upper extremity function and grip strength.

As conclusion, further studies may examine the effects of surgery on upper extremity functionality, hand-grip strength, and quality of life in patients with AIS using both objective and patient-reported assessment tools.

\section{Our limitations}

The limitations of our study were the lack of preoperative 
evaluation of patients, pain severity and localization were not questioned and the presence of shoulder pathology was not clinically evaluated.

Ethics Committee Approval

Approved by the local ethics committee.

Informed Consent

Retrospective study.

Peer-review

Internally peer-reviewed.

Authorship Contributions

Concept: N.Ö., N.B., R.Ş., A.E.K.; Design: N.Ö., N.B., R.Ş., G.B., A.Ç.Y, A.E.K., I.A.; Supervision: N.Ö., N.B., R.S.., G.B., A.Ç.Y, A.E.K., I.A.; Fundings: N.Ö., N.B.; Materials: N.Ö., N.B.; Data: N.Ö., N.B.; Analysis: N.Ö., N.B.; Literature search: N.Ö., N.B., R.Ş., G.B., A.Ç.Y, A.E.K., I.A.; Writing: N.Ö., N.B., R.S.., G.B., A.Ç.Y, A.E.K., I.A.; Critical revision: N.Ö., N.B., R.Ş., G.B., A.Ç.Y, A.E.K., I.A.

\section{Conflict of Interest}

None declared.

\section{REFERENCES}

1. Konieczny MR, Senyurt H, Krauspe R. Epidemiology of adolescent idiopathic scoliosis. J Child Orthop 2013;7:3-9. [CrossRef]

2. Jada A, Mackel CE, Hwang SW, Samdani AF, Stephen JH, Bennett JT, et al. Evaluation and management of adolescent idiopathic scoliosis: a review. Neurosurg Focus 2017;43:E2. [CrossRef]

3. Cheng JC, Castelein RM, Chu WC, Danielsson AJ, Dobbs MB, Grivas TB, et al. Adolescent idiopathic scoliosis. Nat Rev Dis Primers 2015;1:15030. [CrossRef]

4. Goldberg MS, Mayo NE, Poitras B, Scott S, Hanley J. The Ste-Justine Adolescent Idiopathic Scoliosis Cohort Study. Part II: Perception of health, self and body image, and participation in physical activities. Spine (Phila Pa 1976) 1994;19:1562-72. [CrossRef]

5. Theroux J, May S Le, Fortin C, Labelle H. Prevalence and management of back pain in adolescent idiopathic scoliosis patients: A retrospective study. Pain Res Manag 2015;20:153-7. [CrossRef]

6. Turgut E, Gur G, Ayhan C, Yakut Y, Baltaci G. Scapular kinematics in adolescent idiopathic scoliosis: A three-dimensional motion analysis during multiplanar humeral elevation. J Biomech 2017;61:22431. [CrossRef]

7. Borstad JD. Resting position variables at the shoulder: evidence to support a posture-impairment association. Phys Ther 2006;86:54957.

8. Uhl TL, Kibler WB, Gecewich B, Tripp BL. Evaluation of clinical assessment methods for scapular dyskinesis. Arthroscopy 2009;25:1240-8. [CrossRef]

9. Ludewig PM, Phadke V, Braman JP, Hassett DR, Cieminski CJ, LaPrade RF. Motion of the shoulder complex during multiplanar humeral elevation. J Bone Joint Surg Am 2009;91:378-89. [CrossRef]

10. Ludewig PM, Reynolds JF. The association of scapular kinematics and glenohumeral joint pathologies. J Orthop Sports Phys Ther 2009;39:90-104. [CrossRef]

11. Kebaetse M, McClure P, Pratt NA. Thoracic position effect on shoulder range of motion, strength, and three-dimensional scapular kinematics. Arch Phys Med Rehabil 1999;80:945-50. [CrossRef]

12. Rushton PR, Grevitt MP, Sell PJ. Anterior or posterior surgery for right thoracic adolescent idiopathic scoliosis (AIS)? A prospective co- horts' comparison using radiologic and functional outcomes. J Spinal Disord Tech 2015;28:80-8. [CrossRef]

13. Otoshi K, Takegami M, Sekiguchi M, Onishi Y, Yamazaki S, Otani K, et al. Association between kyphosis and subacromial impingement syndrome: LOHAS study. J Shoulder Elbow Surg 2014;23:e300-e7. [CrossRef]

14. Alanay A, Cil A, Berk H, Acaroglu RE, Yazici M, Akcali O, et al. Reliability and validity of adapted Turkish Version of Scoliosis Research Society-22 (SRS-22) questionnaire. Spine (Phila Pa 1976) 2005;30:2464-8. [CrossRef]

15. Ware JE Jr, Sherbourne CD. The MOS 36-item short-form health survey (SF-36). I. Conceptual framework and item selection. Med Care 1992;30:473-83. [CrossRef]

16. Koçyiğit H, Aydemir Ö, Ölmez N, Fişek G, Memiş A. KF-36 nın Türkçe versiyonunun güvenilirliği ve geçerliliği. İlaç ve Tedavi Dergisi 1999;12:102-6.

17. Hudak PL, Amadio PC, Bombardier C. Development of an upper extremity outcome measure: the DASH (disabilities of the arm, shoulder and hand) [corrected]. The Upper Extremity Collaborative Group (UECG) Am J Ind Med 1996;29:602-8. [CrossRef]

18. Düger T, Yakut E, Öksüz Ç, Yörükan S, Bilgütay B, Ayhan Ç, et al. Kol, omuz ve el sorunları (disabilities of the arm, shoulder and HandDASH) anketi Türkçe uyarlamasının güvenirliği ve geçerliği. Fizyoter Rehabil 2006;17:99-107.

19. Pienimaki T, Tarvainen T, Siira P, Malmivaara A, Vanharanta H. Associations between pain, grip strength and manual tests in the treatment evaluation of chronic tennis elbow. Clin J Pain 2002;18:16470. [CrossRef]

20. Rapp van Roden EA, Richardson RT, Russo SA, Rose WC, Chafetz RS, Gabos PG, et al. Shoulder Complex Mechanics in Adolescent Idiopathic Scoliosis and Their Relation to Patient-perceived Function.J Pediatr Orthop 2018;38:e446-e54. [CrossRef]

21. Lin JJ, Chen WH, Chen PQ, Tsauo JY. Alteration in shoulder kinematics and associated muscle activity in people with idiopathic scoliosis. Spine 2010;35:1151-7. [CrossRef]

22. Gur G, Turgut E, Ayhan C, Baltaci G, Yakut Y. Acute effects of spinal bracing on scapular kinematics in adolescent idiopathic scoliosis. Clin Biomech 2017;47:14-9. [CrossRef]

23. Yu WS, Chan KY, Yu FWP, Yeung HY, Lee KM, Ng KW, et al. Lower handgrip strength in girls with adolescent idiopathic scoliosis (AIS) a case-control study. Stud Health Technol Inform 2012;176:475.

24. Menon VK, Tahasildar N, Pillay HM, M A. Axial Plane Deformity of the Shoulder in Adolescent Idiopathic Scoliosis. Clin Spine Surg 2017;30:E351-E7. [CrossRef]

25. Pineda S, Bago J, Gilperez C, Climent JM. Validity of the Walter Reed Visual Assessment Scale to measure subjective perception of spine deformity in patients with idiopathic scoliosis. Scoliosis 2006;1:18.

26. Asher M, Min Lai SM, Burton D, Manna B. The reliability and concurrent validity of the scoliosis research society-22 patient questionnaire for idiopathic scoliosis. Spine 2003;28:63-9. [CrossRef]

27. Burd TA, Pawelek L, Lenke LG. Upper extremity functional assessment after anterior spinal fusion via thoracotomy for adolescent idiopathic scoliosis: prospective study of twenty-five patients. Spine (Phila Pa 1976) 2002;27:65-71. [CrossRef]

28. Rushton PR, Grevitt MP. What Is the Effect of Surgery on the Quality of Life of the Adolescent With Adolescent Idiopathic Scoliosis? A Review and Statistical Analysis of the Literature. Spine 2013;38:786-94. [CrossRef]

29. Mariconda M, Andolfi C, Cerbasi S, Servodidio V. Effect of surgical correction of adolescent idiopathic scoliosis on the quality of life: a prospective study with a minimum 5-year follow-up. Eur Spine J 2016;25:3331-40. [CrossRef] 
30. Simony A, Hansen EJ, Carreon LY, Christensen SB, Andersen MO. Health-related quality-of-life in adolescent idiopathic scoliosis patients 25 years after treatment. Scoliosis 2015;10:22. [CrossRef]
31. Pellegrino LN, Avanzi O. Prospective evaluation of quality of life in adolescent idiopathic scoliosis before and after surgery. J Spinal Disord Tech 2014;27:409-14. [CrossRef]

\section{Skolyoz Cerrahisi Uygulanan Adolesan Idiyopatik Skolyozlu Hastalarda Üst Ekstremite Fonksiyonelliğinin İncelenmesi}

Amaç: Adolesan idiyopatik skolyozun (AIS) omuz disfonksiyonu ve üst ekstremite fonksiyonelliği üzerine olan etkisi halen tam olarak anlaşılmamıştır. Bu çalışmada AIS'in üst ekstremite fonksiyonelliği ve yaşam kalitesi üzerine etkilerini araştırmayı amaçladık.

Gereç ve Yöntem: Çalışmaya adolesan idiyopatik skolyoz nedeniyle ameliyat edilen 37 hasta katıldı. Üst ekstremite fonksiyonelliği, Kol, Omuz ve El Sorunları Anketiyle (DASH-T), kaba kavrama kuvveti Jamar el dinamometresiyle, yaşam kalitesi SF-36 ve Skolyoz Araştırma Cemiyetinin Sağlık İlişkili Yaşam Kalitesi-22 (SRS-22) ile değerlendirildi.

Bulgular: Hastaların yaş ortalaması $17.08 \pm 2.96$ yıl, ortalama takip süresi $34.44 \pm 25.37$ aydı. DASH-T skoru $14.79 \pm 17.35$ idi. Hastaların yaşam kalitesi skorları iyi düzeydeydi. Sağ el kaba kavrama kuvveti $19.84 \pm 8.89 \mathrm{~kg}$, sol el kaba kavrama kuvveti $18.97 \pm 8.01 \mathrm{~kg}$ idi. Sağ ve sol el kaba kavrama kuvveti arasında istatistiksel olarak anlamlı fark yoktu $(p=0.67)$. DASH-T ile SRS-22 ağrı $(r=-0.46, p=0.01)$ ve SF-36 ağrı $(r=0.54$, $p=0.01)$ arasında orta düzeyde negatif, SF-36 sosyal fonksiyon ile zayıf pozitif bir ilişki vardı. $(r=-0.38, p=0.03)$. Cobb açısı $(\Delta)$ ile SRS-22, SF-36, DASH-T ve el kaba kavrama kuvveti arasında istatistiksel olarak anlamlı bir ilişki yoktu.

Sonuç: İleri çalışmalar, hem objektif hem de hasta tarafından bildirilen değerlendirme araçlarını kullanarak AIS'li hastalarda cerrahinin üst ekstremite fonksiyonelliği, kaba kavrama kuvveti ve yaşam kalitesi üzerine etkilerini inceleyebilir.

Anahtar Sözcükler: Adolesan idiyopatik skolyoz; DASH-T; SRS-22. 